\title{
The Reconstruction of Police Legal Culture to Interpreting Law in the Democratic Era
}

\author{
Christina Maya Indah \\ Law Faculty of Satya Wacana Christian University \\ Salatiga, Indonesia \\ mayauksw@yahoo.co.id
}

\begin{abstract}
Within democracy in Indonesia, it is necessary to judge the police's accountability. This sociolegal research had a purpose to analysis discourse on the construction of social reality of police's legal culture within the law interpretation, which was related to police power. There was found a discourse of dogmatic police work with a positivistic law interpretation formed by pathological bureaucracy with paramilitary culture. It was necessary to have a reconstruction from the police to become populist, community building oriented, and inner conscience to be humanistic.
\end{abstract}

Keywords-Police; Legal Culture; Democracy; Indonesia; Reconstruction.

\section{INTRODUCTION}

Nowadays, it is still perceived necessary to reconstruct the police legal culture of Indonesian Police into a societalparadigm culture to fit into the process of democracy. This paper reflects the police culture which became an obstruction towards democracy. There was an expectation that through democracy, there would be a reposition of Indonesian Police status from a mere country tool/state agency into an independent institution that devoted itself towards social necessities/a public agency. Police, when executing a social control, had a power monopoly or authority to face with the society. The society was often situated in the powerless position. The reinforcement of democratic legal culture had been an agenda within the body reformation of Indonesian Police.

\section{RESEARCH METHOD}

This research was a socio legal study research that represented the connection among the contexts in which the police as a legal symbol existed [1]. The research was conducted in 2015-2016 in Central Java. The law was viewed as an existing empirical reality and functioned in a socio cultural context, even socio political context to examine how the police could bring the democracy into reality and analyze various social context on police legal culture into reality.

This research had the published data by interview towards the police elements in the row of Central Java Police Department.

Whereas the research questions were:

1. How was the legal culture of Indonesian Police all this time?

2. How was the reconstruction of police legal culture into a democratic police institution?

\section{RESEARCH FINDING \& DISCUSSION}

Police legal culture was inseparable with a context or contextualization that included social setting which bore the values taken up or the power of social, law, culture existed and influenced the actor's interpretation

Culture is seen to be the product of thought, language and interaction expressed in images, symbols, rituals, and styles of behaviour [2].

The existing political condition had shaped the law[3] Tamanaha had an opinion that democracy was a procedure of decision making that ruled how to determine a content or substance of the law that had a purpose of social wealth, substantive equation, and protection over cultural rights[4] One indication was that sometimes democracy was an access towards justice. Bedner cited UNDP about the concept of justice access, i.e. the ability of an individual (or society) to seek and reach the solution trough a formal or informal institution of justice, and in accordance with human rights[5].In democracy, it was expected that the police would have a culture that protect the society's rights to get and have access to justice, in accordance with civilian police achievements. Democracy could also mean protection and justice for marginal groups. The police should have an attitude more as a server rather than a power holder. They should not become the extension of political needs, but should devote to the liberated and independent judicature system.

Democratic police also meant as police with accountability whose characters were 'equal treatment of all groups' and respect or the dignity of individuals[6]. Policing in a democracy necessitates that a police organisation is bound by such a legal obligation and imbued with a corresponding attitude towards the rule of law and society in general [7]

In such cases that attracted society's attention and arouse untrustworthiness towards police's action of 'to serve and to protect', were caused by the displacement of goal in revering the substance of democratic police. Those cases were:

1. The arrest of Mrs. Minah (55) in Banyumas, Central Java, for stealing three pieces of cacao seeds from PT. Rumpun Sari Antan plantation.

2. The case of stealing $2 \mathrm{~kg}$ of silk-cotton seeds from the harvest leftover valued Rp. 10,000,- by Manisih with her 2 children and her nephew in Batang, Central Java. 
The police's arrest was viewed overwhelming since it was a habit in the society..

3. The arrest of KlijoSumarto (76) by Sector Police of Godean, Sleman, for the accusation of stealing a stem of banana valued Rp. 2,000,-. This case had arisen the reaction from Jogja Police Watch .

Based on those cases and also from the intensive interview with the police, it was analyzed that:

3. Small people were always in the weak position when facing with law and injustice. Those cases above described the partial and discriminative attitude of the police's action in the law enforcement which only reached the powerless society.

4. The police was not prepared for democracy and lacked of community support character in its job. In accordance with this community era, it seemed that the police only gave minor place for public contributions to take part to value the police's tasks. The police culture indicated that the police had not been democratic for rejecting the public room with the closed and non-dialogic attitude. Those were shown from the cases that attracted people's attention and had lowered their trustworthiness towards Indonesian Police.

5. Police legal culture was more of a culture that placed commitment onto the procedural justice and normative stipulation as a guidance to act, than the substantive justice they would like to reach. The police's legal interpretation was merelyliteralegis interpretation, just as far as procedural concern, and did not view the social justice context.

The police had not yet represented the public sense of justice. Besides the cases, there were also other interesting cases, i.e.:

1. The case of mistreatment by an investigator in the arrest case of assumed motorcycle stealing in Tingkir Police Sector Salatiga.

2. The police's act of reporting Haris Azhar of Kontras Social Institution about vilification criminal act, because he had conveyed the testimony from Freddy Budiman, the dead-executed prisoner, to the media; which within his execution disclosing the involvement of Indonesian Police Officials and BNN in the web of narcotics.

The cases had described that police was not ready for democracy to change the truth centralistic monopoly according to the perception of power holder and the facts rolled on by the society. The police tended to use the power approach more than the service approach towards the society who tried to correct the internal body of Indonesian Police. The police's repression on the cases was viewed as a destructive power from the police institution.

Based on the research result through intensive interview, it described that the positivistic paradigm nowadays still became police's characteristics; the police paradigm with legalistic formal culture plus patronized culture adhered to paramilitary character, the execution of police task at the time being had still not yet fully fitted to public face of justice for providing legal protection to the justice seeker. The police tended to put forward 'legalistic style' model rather than 'service style'. The police was inclined to have legal culture with legalistic style which emphasized on 'legal rules' and paid less attention towards social justice value[8].

The case of vilification by the activist Haris Azhar who tried to criticize the Indonesian Police in the testimony case of Fredy Budiman and the arrest of the activists who criticized the government officials had made the police lacked of participation in democracy process.

The police was the manifestation of the law itself that had their own social habitat. The police types had changed according to the change of the social habitat itself, in which the change of democratic society organizing also changed the social habitat[9]. Democratization process had an indication to give emphasis to place the people as the subject of law and became the orientation of protection (to protect, to respect, and to fulfill human rights). That paradigm was in compliance with the change that became more reinforced to protect people and control the power. The social, economic, politic, and legal changes nowadays had the transformative perspective and being tested to transform the social relation into the fairer relation or more of the social reformation that continued the limp social formation.

Discussion of the issue has tended to centre the idea of accountability to the law and to the police authorities as representatives of the people.The police force as a means of obtaining public support for the policies and practices that they believe are right, and outside the police force as a means of ensuring that policing policy is adapted to meet public expectations. The police in democracy "act as the agents of the public.in a democratic society, state power, including that police, must be visible, must have a face, a human face.

The purpose of accountability is to provide a democratic means to monitor and control government conduct. Then accountability should provide assurance in respect to the use of public resources and adherence to the law and publicservice...Accountability mechanisms have distinct functions as well. Many want to hold public authorities accountable for a variety of well-established rules and procedures to prevent unfairness or abuse of power. Citizens want to have the final say because the ultimate authority and ownership of the state rests with the citizens [10].

The legal and social phenomena which became the background of police work, had become the source of tension for police within the bumps between the necessities and shaping the police legal culture as the way of doing or the idea or value that became the base of police behavior. The bumps of necessities occurred because the police individuals were confronted with bureaucracy demand, society demand, and personal demand which eventually form the police culture in interpreting democracy.

The positivistic paradigm that still encompassed the police, assumed that law was as a will and order from the ruler; it left out the substantial essence of the criminal law which actually was the manifestation of the sense of justice, volontegenerale (public/general will), and 'd'interetcommun' 
(public need)[11].Two particular aspects of the 'form' of the police-public relationship - the police's command of nonnegotiable force and inequality in the reciprocity of information - play a key role in limiting some of the principal aspirations of democratic policing theory. There are permanent barriers to improving the democratic credentials of the police I argue, yet positive and progressive change is still achievable[12].

Beside that, actually in the ineffectiveness of the state ' $\mathrm{s}$ attempts to combat corruption has also been caused by the weakness of judicial corruption. Corruption, defined as the "misuse of public office for personal gain", focuses on the individual civil servant as a key actor. Although institutional settings and cultural factors matter, it is an individual decision whether or not to engage in a corrupt deal influenced by exceptional temptations seen against public ethics [13].

Police corruption is the misuse of police authority for personal gain. Example include exortion for example demanding the money), and bribery (for example accepting money in exchange for not enforcing the law). A corrupt act is a crime of immoral police officers, and dishonest.Police corruption detracts from the integrity of the police and tarnishes the public image of law enforcement.Police corruption can protects criminal activity. In democracy era, police corruption do not maintain an independent behavior in dealing with corruption and allowing intervention by executive.

Bubandt's writing that consumption and corruption are closely linked throughout Indonesia, where 'eating' is a popular euphemism for corruption. The government's idea of work is to eat the people [14].

Police culture could have two characteristics, i.e. antagonist police and protagonist police. The antagonist police would confront with society. The centralistic monopoly of justice in an investigation would be the police's absolute authority, and the society could only suffer. Police bureaucracy would be bureaucracy of the extension of totalitarian since the police merely functioned as the government tool. Meanwhile, the protagonist democratic police would act in accordance with public sense of justice.

The genealogy of police authority was inseparable with the development of police culture in the militaristic era until democracy. Since Indonesian Police was apart from TNI (Indonesian Soldier) in April 1, 1999 and became civil police, it had become the society's hope that police would not project the militaristic police image anymore, for it brought up the fear; and they really needed to alter their identity to be a truly civilian police who served the society. After being apart from the Indonesian Soldier, the police was not military power anymore, although they still had a monopoly of power and strength to execute the social control as a part of government bureaucracy. However, the militaristic character had been too long that it became deeply rooted in investigation. Police legal culture still made legal interpretation out of the ruler's perspective, so the civilian paradigm (civilian police) had not yet become the whole part of police work.
In authoritarian regimes, the police mission is to intimidate and suppress opposition and to protect the regime. In democratic societies, the police mission is to protect and serve the citizenry, building safe communities by responding to both crime and official corruption and abuse [15].

It was proper for the police to put forward the service legal culture rather than the ruler legal culture. The deconstruction of totalitarian, paramilitary and antagonist legal culture was necessary to change into protagonist, serving and protecting civilian police to be able to cope with the development of democracy. The indications of being civilian police in the democracy nature were, among others: transparency, accountability and being sides with public sense of justice of the justice seekers. Citizens play a variety of important roles in justice, and their involvement is crucial to the functioning of the justice system in a democratic society.

Five elements may be considered as the main ambitions of community policing: proximity, a focus on a wide range of problems in the neighbourhood, prevention, cooperation with other agencies and the promotion of citizen involvement [16].

The contradictory characteristics with democracy in police culture were clannish, secretive, and isolated. Mc. Erlain stated that police culture was 'Code of Silence'[17].In the law enforcer role, the police had a power paradigm with 'paramilitary' paradigm pattern, in which the hierarchy relationship between police and society occurred. In the orderliness guard role, the police was expected to have partnership and parallel paradigm with the society, within the protagonist pattern[18]. A paramilitary organization, even if highly professionalized and bureaucratically efficient, is often not conducive to improving interpersonal communication between the policeman and the community because of inflexibility.

The police as a mere state tool plus its paramilitary characteristic caused the Indonesian Police row tended to submit to the higher authority through state personifications like political elites and executives rather than to society. The characteristic might enable the possible occurrence of state police, in which the police domination as a state tool created the susceptibility of state authority intervention. The police was co-opted as a power tool and a state agency.

In the context of democratic police, then the offering was public police concept, known as civilian police. Police accountability was counted heavily on social service that had a position as a social control agency, and emphasis on accountability to community needs.

The reticence of police bureaucracy by closing from any public criticisms about police work indicated that the police still tended to have antagonist style and opposed to societyand lack of respect for human right. Democratic police should have protagonist style who became society's guardian and protectorof the rights of all people or the fundamental human rights.

Transparancy as a part of public service[19]. But, The dominant characteristic in police culture at the time being was 'isolation' and placed the police observer public into a 
confrontation position. This was surely inappropriate with the police enrolled philosophy that was a community oriented policing. Progressive thinking about how to improved the police paved the way for reform movement. The professional police bureaucracy was administratively efficient, and organizationally separate from political influences.

Democratic police could not be apart from its habitat, the society. The orientation of Community policing meant that police are the public and public are the police. The police officers are those who are paid to give fulltime attention to the duties of every citizen, emphasis on local accountability to community needs. Police should formally recognize the importance of communication with the public and constantly seek to improve its ability to determine the needs and expectations of the public, and to act upon these needs and expectations for acces to justice, and to improve the delivery of police services. A basic principle of a democratic society that the police should be answerable to the public.

Restructuring of Policing is occurring under private as well as government auspices and will have profound effects on public safety, equity, human rights, and accountability. These effects are discussed, along with the trade-offs they represent for public policy[20].The democratization agenda in police bureaucracy is important to be left to the state. While the state in the form of government, parliament, political parties has suffered from lack of public trust and plagued by credibility, the role of civil society have become more important in ensuring the democratic police will actually be carried out.

Multiple levels of control, distinguishes democratic police from police governed by other regimes. No single accountability structure is sufficient; rather, structures at the internal, state and social levels are all necessary [21].

The aspect of civil society role in escorting police democratization was necessary to assure police accountability and give recommendation for policy and procedure alteration. Therefore, reformation to be civilian was the reformation in the Indonesian police body and built the civilization culture for democratic police personifications.

\section{CONCLUSION}

The reduction in democracy interpretation by the police was interconnected with the police characteristic which had legalistic style model in paramilitary paradigm that emphasized more on official perspective rather than services for public perspective. The positivistic paradigm the police convicted had caused the police to merely execute the closed rigid law in a repressive goal, so the police got a gap with the community they served. The police became further apart from their habitat.

Within the era of democracy in Indonesia, whether Indonesian Police show off more as rulers or as public servants for the justice seekers. The discourse towards police's repressiveness on minor cases such as the stealing of 5 pieces of cacao had hurt the 'public sense of justice', and viewed as a destructive power from the police institution.
Police work with a positivistic law interpretation formed by pathological bureaucracy with paramilitary culture. It was necessary to have a reconstruction of a dogmatic positivistic legal culture interpretation from the police to become more integrity, populist and community building oriented, responsive, and inner conscience to open the discoursed room of police work to be more inclusive and humanistic.

The culture system that the police had in this democracy era was perceived as not yet lovable police by the society. The police legal culture needed some reconstruction into a civilian police paradigm that did not depend on power-based force as a ruler. Police was a public agent, so the reconstruction of police legal culture into democratization was by doing 'depolicing the police' or constructing the independence of Indonesian Police. In fulfilment Indonesian Police reformation, should be held that Indonesian police must be seen as an essensial element in a democracy, the Indonesian Police are a key factor in a democratic society, and should function as a protector of human rights or should be at the services of human rights, should be representative of and responsive and accountable to the community as a whole.

\section{ACKNOWLEDGMENT}

The author would like to thank the SatyaWacana Christian University, for the Basic Research for its support to this research.

\section{REFERENCES}

[1] Banakar R and M. Travers, Law, Theory and Method in Socio Legal Research, Onati: Hart Publishing Oxford and Portland Oregon, 2005, pp.1-26

[2] Eugenie Samier, "Toward Public Administration as a Humanities Discipline: A Humanistic Manifesto", Halduskultuur, 2005, vol 6, pp. 6-59.(P.28)

[3] Ruti G. Teitel, Transitional Justice: a comprehensive review (Keadilan Transisional: sebuah tinjauan komprehensif ), Jakarta : Elsam Publishing, 2004, p. 9

[4] Tamanaha, B.Z on The Rule of Law: History, Theory, Politics, Cambridge: Cambridge University Press, 2005, p. 91

[5] Adriaan Bedner and Jacqueline Vel, (An Analysis Framework for Empirical Research in the Access towards Justice, in the Socio Legal Study), Sebuah Kerangka Analisis Untuk Penelitian Empiris dalam bidang Akses terhadap Keadilan, dalam Kajian Socio Legal , Bali : Pustaka Larasan, 2012, p.85.

[6] Samuel Walker, The New World of Police Accountability, Thousand Oaks, London, New Delhi : Sage Publications, 2005, p.7-8

[7] Timothy George Shilston, Six Dimensions of police accountability : An aid to needs assessment in international police development missions. International journal of Police science and Management, Volume 18, Issue 1, March 2016

http://journals.sagepub.com/doi/full/10.1177/1461355716638115

[8] James Q. Wilson in Roger Cotterell, The Sociology of Law, An Introduction, second ed., London, Dublin, Edinburgh :Butterworths, 1992, p. 278

[9] Satjipto Rahardjo, Civilian Police in Indonesian Social Change (Polisi Sipil dalam Perubahan Sosial Indonesia), Jakarta : Kompas Publisher, 2002, p.39.

[10] Deni Setyo Bagus Yuherawan, Deconstruction of Legality Foundation in Criminal Law, The History of Legality Foundation and The Concept of Philosophical Renewal in Criminal Law ( Dekonstruksi Asas Legalitas Hukum Pidana, Sejarah Asas Legalitas dan Gagasan Pembaharuan Filosofis Hukum Pidana), Malang : Setara Press, 2014, p.237. 
[11] Ari Salminen and Kirsi Lehto. 2012. "Accountable to Whom? Exploring the Challenge of Multiple Accountabilities in Finnish Public Administration." Haldus kultuur - Administrative Culture 13 (2), p. 150,158 .

[12] Bubandt, N, Sorcery, corruption, and the dangers of democracy in Indonesia, In Journal of the Royal anthropological Institute, Vol.12, 2006, pp.413-431, 2006

[13] Simmel, the Police Form and the Limits of Democratic Policing, The british journal of criminology, 2015) 55 (4): 730-746 first published online April 13, 2015,

http://bjc.oxfordjournals.org/content/55/4/730

[14] Lars Johannsen and Karin Hilmer Pedersen. 2012. "How to Combat Corruption: Assessing Anti-Corruption Measures from a Civi Servant's Perspective." Haldus kultuur - Administrative Culture 13 (2),p.132.(130-146)

[15] Michael D.Wiatrowski,Jack A Goldstone, The Ballot and the Badge: Democratic Policing, April 2010, Volume 21, p.79-92,jounal of democracy,http://www.journalofdemocracy.org/article/ballot-andbadge-democratic-policing.

[16] Terpstra J (2009) Community policing in practice: ambitions and realization. Policing: A Journal of Policy and Practice 4(1): 64-72.
, Google Scholar, J Terpstra - Policing, 2009 policing.oxfordjournals.org

[17] Linda S. Miller, Karen M. Hess, The Police In The Community, Strategy for the $21^{\text {st }}$ Century, $3^{\text {rd }}$ ed., USA : Wadsworth/Thomson Learning, 2002, p.34

[18] Venla Mäntysalo. 2015. "The Importance of Transparency in Ethica Governance: Current Research and Finnish Citizens' Perceptions.' Administrative Culture 16 (1), 48-67.

[19] David H. Bayley and Clifford D. Shearing, The Future of Policing, Law \& Society Review, Vol. 30, No. 3 (1996), pp. 585-606,Published by: Wiley on behalf of the Law and Society Association,DOI: 10.2307/3054129,,Stable URL: http://www.jstor.org/stable/3054129.

[20] Stone CE, Ward HH (2000), Democratic policing: a framework for action. Policing and Society 10(1): 11-45. , Google Scholar.CE Stone, HH Ward - Policing and Society: An International, 2000

http://journals.sagepub.com/doi/abs/10.1177/1461355715618331 